\title{
ELEVATING THE PRE-SERVICE TEACHERS' TRANSLATION SKILL BASED ON LEARNER AUTONOMY
}

\author{
Rafiqa, Sukmawati Yasim \\ Universitas Sulawesi Barat \\ rafika@unsulbar.ac.id
}

\begin{abstract}
This paper attempts to improve the pre-service teachers based on students' learner Autonomy. The EFL classroom by first describing the role of translation in EFL learning, then exploring Learner Autonomy can be regarded as an effective teaching method to elevate students' Translation skill. Research setting at West-Sulawesi University, Majene West Sulawesi. The method was used pre-experimental design by one group pretest and posttest. Over 22 students programming Translation were the samples of this study by using purposive sampling technique. To collect the data, researchers used translation test as instrument, it was applied on pretest and posttest. To improve students' skill towards Translation, Learner Autonomy was implemented for 12 meetings within 4 months. The notion of learner independence or learner autonomy moves into an area where learners can direct their own learning particularly in translating the sentences and text provided during the class. It could mean those learning activities which take place without the immediate intervention of the teacher. In this scenario, learners set their own objectives and follow strategies devised by them to fulfill them. This is in turn facilitates the learner to become more efficient and effective when they study independently. Learners are compelled to assume responsibility for their own learning. The result of this study was Learner Autonomy successfully elevated the pre-service teachers' Translation.
\end{abstract}

Keywords: Pre-Service Teachers, Translation Skill, Learner Autonomy.

\section{INTRODUCTION}

Indonesia, as an expanding circle country, has widely used English as Foreign language which is commonly explored to be a requirement to be qualified in any job vacancies or higher educational levels. This issue has led the Translation skill becomes one of the most helpful skill to have by scholars, practitioners or other professionals. For a long time in the history of translator training, trainers had assumptions that students or apprentices learn 
to translate simply by translating. As professional translators with little time to devote to reflection on how to organize teaching and learning, many early trainers limited class activity to asking for on-sight (oral) translation of journalistic and literary texts, with little or no prior preparation on the part of the students, and to offering their own "correct" version as a model after public confirmation that the students' versions lacked professional quality. This approach to training was essentially pedagogical, and of course extremely frustrating for students particularly for pre- service teachers. In this globalization era, the international relation in every sector of life is becoming increasingly significant. Good translation products of various fields are highly needed. To fulfill such needs, the linguists and translators play the most important role in producing reliable translation works in a fastest way (Rogi, 2009).

Pre-service teacher is a period of guided, supervised teaching. The college student is gradually introduced into the teaching role for a particular class by a mentor or cooperating teacher. Kukari in 2004 contends that pre-service teachers perceived teaching as the transmission of prescribed knowledge from the teacher to the learners, learning was viewed as the absorption and the memorization of prescribed knowledge and a teacher's main role was to transmit prescribed knowledge to the learners who were perceived as "empty" vessels. In addition, as the future teachers, these types of students are expected to have better skill in translation as the soft-skill to understand English references, to assist people to comprehend English textbooks, and to teach how to translate.
The use of the translation method in the EFL classroom is often criticized based on two general arguments. First, translation involving the use of the mother tongue deprives students of opportunities to receive sufficient L2 input. Second, translation triggers L2 learning errors due to negative interference from the mother tongue. EFL teachers are therefore strongly encouraged to abandon the translation method.

However, teachers in tertiary level have been seemingly found some difficulties in terms of improving these pre-service teachers' Translation skill. One of the challenges facing foreign language teachers is to make students become self-reliant, autonomous learners who can pursue their own learning and survive outside the sheltered environment of the classroom. The aim of this article is to discuss the concept of learner autonomy, the role of teacher and learner in an autonomous classroom and how to promote learner autonomy in EFL writing classrooms. Special focus is placed on the criticism of the traditional way of teacher feedback provision and the use of peer feedback activity as a means to help language learners to be responsible and assume responsibility for their ownlearning.

Accordingly, This paper attempts to improve the pre-service teachers based on students' learner Autonomy. The EFL classroom by first describing the role of translation in EFL learning, then exploring Learner Autonomy can be regarded as an effective teaching method to elevate students' Translation skill.

Research setting at West-Sulawesi University, Majene West Sulawesi. The method was used 
pre-experimental design by one group pretest and posttest. Over 22 students programming Translation were the samples of this study by using purposive sampling technique. To collect the data, researchers used translation test as instrument, it was applied on pretest and posttest. To improve students towards Translation, Learner Autonomy was implemented for 12 meetings within 4 months. The data collected was analyzed by SPSS 18 .

\section{LITERATURE REVIEW}

\subsection{Translation Skill}

Translation is the communication of the meaning of a source-language text by means of an equivalent target-language text (Namit, 1992). The English language draws a terminological distinction (not all languages do) between translating (a written text) and interpreting (oral or sign-language communication between users of different languages); under this distinction, translation can begin only after the appearance of writing within a language community.

Another definition of translation, according to Lin (2008), is "expressing the sense of words or text in another language," either from English to Urdu or vice versa in the Taiwanese context. Based on the above two definitions, for EFL learners, translation is a transfer between the first (L1) and the second (L2) language.

A translator always risks inadvertently presenting source-language words or grammar into the target language rendering. On the other hand, such "spill-overs" have sometimes imported useful source language calques and loanwords that have enriched target languages. Translators, including early translators of sacred texts, have helped shape the very languages into which they have translated (Christopher Kasparek, 1983). In this case, there are three basic principles in translation to be executed, monumental document have not changed, and have evolved into the three basic concepts behind all translation, which can be boiled down to the following rules: 1) The translator must comprehend perfectly the source language; 2) The translator must comprehend perfectly the target language; 3) The translator must be knowledgeable in the subject matter. No matter what else you think about translation as a science, these three precepts are universal: The purpose of translation is to take the meaning of a document and bring it over into the target language, and to do this you must have a clear understanding of these three parts of the equation.

Nida and Taber (1982) say that many factors are crucial to the process of translating and no explanation of translating can claim to comprehensive if these factors are not systematically considered. Translation is a complex process, involving linguistic and nonlinguistic factors. Many reports convinced that foreign language students, especially those who major in English had difficulties with equivalence and variance. Equivalence is associated with the problems with matching the word of a source language and that of a target language that represents an accurate concept. Students commonly get into a real trouble with searching the most appropriate word in the target 
language. While variance refers to the problems of differences in language aspects which are not solely related to vocabulary, but also the idea of producing system and the way of thinking of in the source language. Except for this, students also had difficulty with grammatical, cultural aspects and idiomatic expressions in translating the texts (Ahmad, 2009).

According to Ahmad in 2015, based on the current observation, student-centered teachinglearning process has been difficult to set up. At the beginning of the class the students were asked to prepare themselves at home before entering the class. It did not work, however. In this class, the students were randomly asked to translate the texts of the book entitled: The Life of Prophet Muhammad, S.A.W. and His Moral Teachings. Most of them got into a real trouble when asked to do the translation. However, they did not refuse when they were instructed to translate the texts of the book, but it indicated that some of them did not understand what they were translating. They were unable to create an equivalent meaning in the target language (TL), language that accurately represents the meaning of the source language (SL), English. Even some of them got embarrassed.

\subsection{Learner Autonomy}

Autonomy in learning and teaching plays a pivotal role for language acquisition and by knowing learners VAK strategy (visual, auditory, kinesthetic), teachers can perform better. Also, such teachers who are aware of learners' preferences in learning styles are successful in their teaching. Therefore, this study aimed at investigating the relationship between EFL learners' autonomy and their sensory learning style. Having knowledge of language especially English which is the international language, is a main tool of communicate with other people (Khojasteh \& Pishkar, 2015).

Holec in Ali (2012), the concept of learner autonomy has been central to the Council of Europe's thinking about language teaching and learning since 1979, when Henri Holec wrote Autonomy and foreign language learning Holec began by defining learner autonomy as the "ability to take charge of one's own learning", noting that this ability "is not inborn but must be acquired either by 'natural' means or (as most often happens) by formal learning, i.e. in a systematic, deliberate way", and pointing out that "To take charge of one's learning is to have $[\ldots]$ the responsibility for all the decisions concerning all aspects of this learning [...]"

Holec's report was a contribution to the Council of Europe's work in adult education, which sought to promote the learner's freedom "by developing those abilities which will enable him to act more responsibly in running the affairs of the society in which he lives". When learner autonomy is one of its defining goals, adult education becomes an instrument for arousing an increasing sense of awareness and liberation in man, and, in some cases, an instrument for changing the environment itself. From the idea of man "product of his society", one moves to the idea of man "producer of his society Learner 
autonomy, in other words, belongs together with the idea that one of the functions of (adult) education is to equip learners to play an active role in participatory democracy. That is why it remains central to the Council of Europe's educational concerns. According to a large body of empirical research in social psychology, autonomy - "feeling free and volitional in one's actions"- is a basic human need. It is nourished by, and in turn nourishes, our intrinsic motivation, our proactive interest in the world around us. This explains how learner autonomy solves the problem of learner motivation: autonomous learners draw on their intrinsic motivation when they accept responsibility for their own learning and commit themselves to develop the skills of reflective self-management in learning; and success in learning strengthens their intrinsic motivation. Precisely because autonomous learners are motivated and reflective learners, their learning is efficient and effective (conversely, all learning is likely to succeed to the extent that the learner is autonomous). And the efficiency and effectiveness of the autonomous learner means that the knowledge and skills acquired in the classroom can be applied to situations that arise outside the classroom.

\section{FINDING AND DISCUSSIONS}

Based on the results of students test on pretest and posttest, they were classified into formula then distributed below:

Table 2

Students classification score

\begin{tabular}{|c|l|c|c|c|c|c|}
\hline \multirow{2}{*}{ No Classification } & \multirow{2}{*}{ Range } & \multicolumn{2}{c|}{ Pre Test } & \multicolumn{2}{c|}{ Post Test } \\
\cline { 4 - 7 } & & & $\mathrm{F}$ & $\mathrm{P}$ & $\mathrm{F}$ & $\mathrm{P}$ \\
\hline 1 & Excellent & $9696-100$ & 0 & $0 \%$ & 2 & $9 \%$ \\
2 & Very Good & $86-95$ & 0 & $0 \%$ & 9 & $41 \%$ \\
3 & Good & $76-85$ & 0 & $0 \%$ & 11 & $50 \%$ \\
4 & Fairly Good & $66-75$ & 0 & $0 \%$ & 0 & $0 \%$ \\
5 & Fair & $56-65$ & 9 & $41 \%$ & 0 & $0 \%$ \\
6 & Poor & $36-55$ & 7 & $32 \%$ & 0 & $0 \%$ \\
\hline & Very poor & $00-35$ & 6 & $27 \%$ & 0 & $0 \%$ \\
\hline
\end{tabular}


The table above showed scores both of students pre-test score and students post-test score. Students got fair, poor and very poor classification after calculated pretest score. Thus, after conducted the treatment, students got excellent, very good and good classification on the post test score. It showed that classification score from pre-test to post-test was elevating.

This study addressed the test to measure preservice teachers' improvement in terms of translation skill over the Learner Autonomy. To find out the answer, the data of the tests (pre-test and posttest) were submitted to SPSS statistical program. The purpose of using tests was to show pre-service teachers' improvement toward their translation skill based on Learner Autonomy.

\begin{tabular}{|c|c|c|}
\hline Type of the Test & Mean Score & $\begin{array}{c}\text { Standard Devia- } \\
\text { tion }\end{array}$ \\
\hline Pre-Test & 60.6 & 7.65 \\
\hline Post-Test & 82.6 & 7.71 \\
\hline
\end{tabular}

\begin{tabular}{|c|c|c|}
\hline Variable & t-Value & t-Table \\
\hline T1-T0 & 5.098 & 1.708 \\
\hline
\end{tabular}

The data depicts the information that there was a significant improvement from the pre-test and the post-test. As seen clearly on the table that the mean score was only 60.6 while the post-test reached 82.6. It means that the alternative hypothesis was accepted and null hypothesis was rejected. This indicated that Learner Autonomy elevated the pre-service teachers' translation skill at English Education study program of West-Sulawesi University.

\section{CONCLUSIONS}

EFL learners have a natural tendency to use translation to comprehend any reading sources. In elevating the English Education students or Preservice teachers, then Learner Autonomy can be an effective way to be implemented. The results showed that there was a significant improvement of preservice teachers' translation skill measured by pre-test and post-test of translation text. Further, the results demonstrated that teachers as the facilitators have undeniable role in promoting learners' autonomy. Furthermore, several factors were identified as the most important factors contributing to learners' autonomy. Some these factors were involving students in the class, giving them opportunity to make decision about the content of material, the activities, teaching plan, the kind of evaluation, and so on. More importantly, it was found out that students should be provided with opportunity to learn from each other and have cooperative learning in order to develop their translation skill.

\section{BIBLIOGRAPHY}

Ahmad, S. (2009). Research report entitled: The Impact of prior knowledge of the English Department Students of the Tarbiyah Faculty IAIN Ar-Raniry on their translation class performance. Jurnal Pendidikan, 6(3), 125-145.

Ahmad, Syarwan. 2015. Improving Students Skills in Translations by Using StudentsTeams Achievement Division (STAD) Technique. AL-TA'LIM JOURNAL 22 (2), 2015, (119-128) (Print ISSN 1410-7546 Online ISSN 2355-7893).

Ali, Shamim. 2012. Integrating Translation into TaskBased Activities - A New Direction for ESL Teachers . LANGUAGE IN INDIA Strength for Today and Bright Hope for Tomorrow Volume 12: 8 August 2012 ISSN 1930-2940. 
Christopher Kasparek, 1983. The Translator's Endless Toil, The Polish Review, vol. XXVIII, no. 2, pp. 84-87.

Khojasteh, Z., \& Pishkar, K.(2015). The Relationship between Iranian EFL Learners' Sensory Learning Style and Their Autonomy Level. Journal of Applied Linguistics and Language Research, 2(6), 179-189.

Lin, C. C. (2008). Lectures. Tamkang University

Namit Bhatia, ed., 1992. The Oxford Companion to the English Language. Oxford Press, pp. 1,051-54.
Nida, Eugine. A and Taber, Charles. A, 1982. The theory and practice of translation. E.J Brill: Nedherlands.

Rogi, S. (2009). Beberapa masalah dalam Penerjemahan. Paper presented at the Seminar held by Department of Germany, Faculty of Literature, Sam Ratulangi University, Manado. 